International Journal of Biology, Pharmacy and Allied Sciences (IJBPAS)

'A Bridge Betuen Caboratory and QRendo'

www.ibpas.com

\title{
RP- HPLC METHOD FOR SIMULTANEOUS DETERMINATION OF LAMIVUDINE, ZIDOVUDINE AND NEVIRAPINE FROM THEIR COMBINED TABLET DOSAGE FORM
}

\author{
SHAMILI, NAGAMALLIKA $\mathbf{G}^{*}$, SUREKHA $\mathbf{G}^{3}$, RAMAKRISHNA N, \\ SRINIVASARAO J
}

Department of Pharmaceutical Chemistry, St.Mary's College of Pharmacy, St. Francis Street, Hyderabad, Telangana- 500025, India

*Corresponding Author: Email: mallikagorantla 7@yahoo.co.in; +917416694708

Received $3^{\text {rd }}$ Jan. 2018; Revised $7^{\text {th }}$ Feb. 2018; Accepted $16^{\text {th }}$ March 2018; Available online $1^{\text {st }}$ May 2018 DOI: https://doi.org/10.31032/IJBPAS/2018/7.5.4445

\begin{abstract}
A novel, sensitive and selective reverse phase high performance liquid chromatographic method was developed and validated for the simultaneous determination of lamivudine, zidovudine, and nevirapine in tablet formulation. The chromatographic separation was achieved on Inertsil, ODs C18 4.6 x $150 \mathrm{~mm}, 3.5 \mathrm{~mm}$ column by means of a mobile phase containing a mixture of Ammonium acetate buffer $\mathrm{pH}$ 5.5, acetonitrile and methanol in the ratio of 50:30:20 v/v at a flow rate of $1.2 \mathrm{ml} / \mathrm{min}$ at an ambient temperature and detection was carried out at $260 \mathrm{~nm}$.Clear chromatography peaks were identified with retention times of $2.457 \mathrm{~min}$ for lamivudine, $3.327 \mathrm{~min}$ for zidovudine and $4.813 \mathrm{~min}$ for nevirapine. The urbanized technique was validated as per ICH guidelines regarding specificity, linearity, accuracy, precision, LOD, LOQ and robustness and the method shows excellent linearity and correlation coefficients of lamivudine, zidovudine and nevirapine were 0.9997, 0.9998 and 0.9998 correspondingly. The \% means recoveries of drugs were in between 98.5-100.03 and $\%$ RSD for repeatability and intermediate precision was less than $2 \%$. Therefore, the proposed method can be in use for the determination of Lamivudine, Zidovudine, and Nevirapine in various pharmaceutical dosage forms during regular and quality-control analysis.
\end{abstract}

Keywords: lamivudine, zidovudine and nevirapine, Simultaneous determination, RPHPLC, tablets 


\section{INTRODUCTION}

Human Immunodeficiency Virus (HIV) has been one of the most devastating bloodborne viruses affecting a large pediatric and adult population across the earth. Due to the development thereafter of various antiretroviral (ARV) agents, it has led to the major decrease in the morbidity and mortality rates of the HIV infected population. The standard ARV therapy in the treatment of these HIV-infections entail the use of combination drug therapy, usually a triple combination such as twonucleoside or nucleotide reverse transcriptase inhibitors (NRTIs) as a backbone and a non nucleoside reverse transcriptase inhibitor (NNRTI) ${ }^{[1,2,3]}$. Out of various existing ARV drugs currently recommended by World Health Organization for HIV infection in the pediatric population in resource-limited countries, the combination of zidovudine/lamivudine (NRTI backbone) and nevirapine (NNRTI) is considered as one of the preferred ARV treatment Lamivudine and Zidovudine are synthetic nucleoside analogs and are phosphorylated intracellularly by kinases to its active 5'triphosphate metabolites, lamivudine triphosphate (LTP) and zidovudine triphosphate (ZDV-TP). These active forms are incorporated into HIV DNA by HIV reverse transcriptase resulting in chain termination. Chemically lamivudine is 4-
amino-1-[(2R,5S)-2-(hydroxymethyl)-1,3oxathiolan-5-yl]-1,2-dihydropyrimidin-2one having a molecular formula of C8H11N3O3S, molecular weight is 229.3 $\mathrm{gm} / \mathrm{mol}$. and melting point is $160-162^{\circ} \mathrm{C}$. Soluble in water, sparingly soluble in methanol and the PKA value is 14.29. Chemically zidovudine is $1-[(2 \mathrm{R}, 4 \mathrm{~S}, 5 \mathrm{~S})-4-$ azido-5-(hydroxymethyl)oxolan-2-yl]-5methyl-1,2,3,4-tetrahydropyrimidine-2,4dione having a molecular formula of $\mathrm{C} 10 \mathrm{H} 13 \mathrm{~N} 5 \mathrm{O} 4$, molecular weight is $267.2413 \mathrm{gm} / \mathrm{mol}$. and melting point is 159- $160^{\circ} \mathrm{C}$.Soluble in water and the PKA value is 9.95. Nevirapine is a potent, nonnucleoside reverse transcriptase inhibitor (NNRTI) used in combination with nucleoside analogs. Nevirapine directly binds to reverse transcriptase (RT) and blocks the RNA and DNA-dependent polymerase actions by producing a disturbance of the enzyme's dynamic site HIV-1 RNA to induce a conformational change at the active site and interrupt catalytic activity of the virus to transcribe viral RNA into DNA ${ }^{[4]}$. Chemically nevirapine is 2-cyclopropyl-7-methyl$2,4,9,15$ tetraazatricyclo $\quad\left[9 \cdot 4 \cdot 0.0^{\wedge}\{3,8\}\right]$ pentadeca-1(15),3,5,7,11,13-hexane-10-one having a molecular formula of C15H14N4O, molecular weight is 266.2 $\mathrm{gm} / \mathrm{mol}$. and melting point is $196.06{ }^{\circ} \mathrm{C}$. Soluble in DMS, sparingly soluble in DCM 
and the PKA value is 10.37. These drugs, when given as a fixed dose combination product rather than individual entities, has shown to get better therapy in situation of continued virological suppression and a significant reduction in the mortality rates of the HIV/AIDS infected people ${ }^{[5,6]}$.Progress of fixed-dose combination is frequently related with many propose challenges such as drug-drug or drugexcipient interactions that could compromise the stability and efficacy of the therapeutic agents.

More number of drugs are introduced into the market every year.Very often there is a time lag from the date of introduction of a drug into the market to the date of its inclusion in pharmacopeias. Hence, standards and analytical procedures for these drugs may not be available in the pharmacopeias. Therefore, it becomes necessary to develop newer analytical methods for such drugs. Analytical methods for the drugs in formulations are not available owing to the interference caused by the excipients. Analytical methods for combination of drugs may not be official in pharmacopeias. LC represents an increasing growth that makes it the most popular method used in a pharmaceutical analysis.

Literature survey reveals a number of analytical methods have been reported for simultaneous determination of lamivudine, zidovudine, and nevirapine in bulk, pharmaceutical dosage forms and biological fluids and also in combination with other antiretroviral drugs. These methods are spectrophotometric techniques, such as; UV Spectrophotometric methods (Vaishali P. Nagulwar* et al., 2009; *Ramesh Jayaprakash et al., 2014) ${ }^{[7,8]}$, as well as in HPLC methods (J.V.L.N. Seshagiri Rao* et al., 2010; Patel, Vandana B et al., 2010 P. V. Vamshi Krishna* et al., 2012; *Anjali Joshil et al., 2012,;Sindhura D* et al., 2013; S. Dharmaraj et al., 2013; T T. Sunitha* et al., 2013; Kokkula Sandhya1 * et al., 2014; Shinde G.S* et al., 2014; P.Satyanarayana1* et al., 2015; Vanitha Prakash1 et al., 2015) ${ }^{[9-19]}$ and also LC-MS (Seshagiri Rao JVLNc * et al., 2012; Utpal Nandi et al., 2013; Arindam Mukhopadhyay* et al., 2016) $\stackrel{[20-22]}{ }$.

The objectives of our study is that, the existing analytical methods require more expensive reagents and solvents and also involve cumbersome extraction and separation processes and also some analytical procedures are not available in the literature due to patent regulations. So, a need was felt to develop an eco-friendly analytical method for simultaneous analysis of Lamivudine, Zidovudine, and Nevirapine by reducing the solvent consumption, by minimizing the buffer strength and $\mathrm{pH}$ of mobile phase than 
reported methods. The proposed method was validated with respect to specificity, linearity, precision, accuracy, and robustness as required by the International Conference on Harmonization to support the suitability of the method ${ }^{[23]}$.

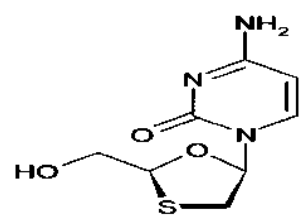

(a)

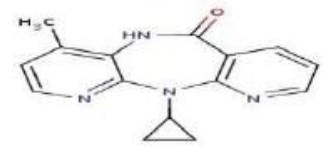

(c)

Figure 1: Chemical structures of (a) Lamivudine, (b) Zidovudine and (c) Nevirapine drugs

\section{MATERIALS AND METHODS}

Lamivudine, Zidovudine and Nevirapine standard drugs were obtained as a contribution sample from Chandra labs, Hyderabad, India. Methanol, water, acetonitrile and glacial acetic acid of HPLC grade and other chemicals of A.R grade were purchased from E. Merk (India) Ltd. Worli, Mumbai, India. The $0.45 \mu$ nylon filters were purchased from Millipore. Lamivudine (150mg), Zidovudine (300mg) \& Nevirapine (200mg) tablets as DUOVIR-N were obtained from Mukesh pharmacy, Hyd.

\section{Instruments and chromatographic conditions}

The HPLC system (waters) Autosampler separation module 2695 consisted of highpressure pump, PDA detector 996, and 20 $\mu \mathrm{L}$ capacity injector loops. The system was well equipped with empower 2 software for monitoring and processing of data. Other types of equipment like Sartorius digital weighing balance, Poloman $\mathrm{pH}$ meter and Fastclean sonicator was used for sample and standard preparations. The analytical column used was Inertsil, ODs C18 $4.6 \times 150 \mathrm{~mm}, 3.5 \mathrm{~mm}$ packed with a particle size of $5.0 \mu$. Ammonium acetate buffer $\mathrm{pH} 5.5$, acetonitrile and methanol in the ratio of 50:30:20 was used as mobile phase at a flow rate of $1.2 \mathrm{ml} / \mathrm{min}$ and the injection volume of $20 \mathrm{ml}$, column oven temperature of ambient and UV detection at $260 \mathrm{~nm}$

\section{Method development}

Various mobile phases with different ratios were tested during the development of HPLC method suitable for the estimation of lamivudine, zidovudine, and nevirapine in tablet formulation. These involve Phosphate buffer $\mathrm{pH} 4.0$ and $\mathrm{ACN}$ in the ratio of 40:60, Phosphate buffer: $\mathrm{pH} 3.5$ $\mathrm{ACN}$ and $\mathrm{MeOH}$ in the Ratio of 20:60:20, Phosphate buffer $\mathrm{pH} 4.0, \mathrm{ACN}$ and $\mathrm{MeOH}$ in the Ratio of 15:65:20, Ammonium acetate buffer $\mathrm{pH}$ 5.5, $\mathrm{ACN}$ and $\mathrm{MeOH}$ in the Ratio of 50:10:40 Ammonium acetate buffer $\mathrm{pH}$ 5.5, $\mathrm{ACN}$ and $\mathrm{MeOH}$ in the Ratio of 50:20:30 and Ammonium acetate buffer $\mathrm{pH} 5.5, \mathrm{ACN}$ and $\mathrm{MeOH}$ in the Ratio of 50:30:20. The mobile phase was selected based on the sensitivity of the process, the time necessary for the 
analysis, easily available solvents and simplicity of preparation. The mobile phase was premixed and filtered through a $0.45 \mu \mathrm{m}$ filter and sonicated for $10 \mathrm{~min}$ to remove gases. Optimization of mobile phase was taken based on various parameters such as retention time, number of theoretical plates and resolution. Methanol was used as a diluent.

Preparation of standard stock solution of lamivudine

Lamivudine working standard of about 10 mg was weighed accurately and transferred into a $100 \mathrm{ml}$ volumetric flask and dissolved then diluted to $100 \mathrm{ml}$ with diluent. $10 \mu \mathrm{g} / \mathrm{ml}$ of solution was prepared by diluting $1 \mathrm{ml}$ of this solution to $10 \mathrm{ml}$ with the diluent.

\section{Preparation of standard stock solution of zidovudine}

Zidovudine working standard of about 10 mg was weighed accurately and transferred into a $100 \mathrm{ml}$ volumetric flask and dissolved then diluted to $100 \mathrm{ml}$ with diluent. $10 \mu \mathrm{g} / \mathrm{ml}$ of solution was prepared by diluting $1 \mathrm{ml}$ of this solution to $10 \mathrm{ml}$ with the diluent.

\section{Preparation of standard stock solution of nevirapine}

Nevirapine working standard of about 10 mg was weighed accurately and transferred into a $100 \mathrm{ml}$ volumetric flask and dissolved then diluted to $100 \mathrm{ml}$ with diluent. $10 \mu \mathrm{g} / \mathrm{ml}$ of solution was prepared by diluting $1 \mathrm{ml}$ of this solution to $10 \mathrm{ml}$ with the diluent.

Preparation of standard solutions of lamivudine, zidovudine, and nevirapine Lamivudine, Zidovudine and Nevirapine working standards of about $50 \mathrm{mg}, 100 \mathrm{mg}$ and $66.6 \mathrm{mg}$ have been weighed precisely and transferred into a $100 \mathrm{ml}$ volumetric flask and dissolved then diluted to $100 \mathrm{ml}$ with the mobile phase. $50 \mu \mathrm{g} / \mathrm{ml}$ of lamivudine, $100 \mu \mathrm{g} / \mathrm{ml}$ of zidovudine and $66.6 \mu \mathrm{g} / \mathrm{ml}$ of nevirapine were prepared by diluting $1 \mathrm{ml}$ of the above solutions to $10 \mathrm{ml}$ with the mobile phase.

\section{Preparation of sample solutions}

Twenty tablets, containing $150 \mathrm{mg}$ of lamivudine, $300 \mathrm{mg}$ of zidovudine and 200 $\mathrm{mg}$ of nevirapine, were weighed accurately and grounded to fine powder, the powder which is equivalent to $50 \mathrm{mg}$ of lamivudine, 100mg of zidovudine and 66.6 $\mathrm{mg}$ of nevirapine were precisely weighed and transferred to $100 \mathrm{ml}$ of volumetric flask and dissolved in sufficient mobile phase, filtered the solution using 0.45micron syringe filter and Sonicated for 5 min and then diluted to $100 \mathrm{ml}$ with mobile phase. $50 \mu \mathrm{g} / \mathrm{ml}$ of lamivudine, $100 \mu \mathrm{g} / \mathrm{ml}$ of zidovudine and $66.6 \mu \mathrm{g} / \mathrm{ml}$ of nevirapine were prepared by diluting $1 \mathrm{ml}$ of above solutions to $10 \mathrm{ml}$ with mobile phase.

\section{Preparation of acetate buffer PH 5.5}

$1.540 \mathrm{gm}$ of Acetate buffer was weighed and dissolved in water and diluted to 1000 
$\mathrm{ml}$ with water and the $\mathrm{pH}$ was adjusted using glacial acetic acid. The buffer was filtered through $0.45 \mu$ filters to remove all fine particles.

\section{Preparation of mobile phase}

50 volumes of Acetate buffer $\mathrm{pH} 5.5,30$ volumes of Acetonitrile and 20 volumes of methanol were mixed together. The solution was degassed in an ultrasonic water bath for 10 minutes and filtered through a $0.45 \mu \mathrm{m}$ filter under vacuum.

\section{Determination of working wavelength ( $\lambda \max )$}

$10 \mu \mathrm{g} / \mathrm{ml}$ solutions of all three drugs in methanol were scanned using UV-Visible spectrophotometer in the wavelength region of 200-400 $\mathrm{nm}$ against methanol as blank. In the absorption curve, the characteristic absorption maxima ( $\lambda \max )$ for Lamivudine, zidovudine and nevirapine drugs in the mixture were at $270 \mathrm{~nm} 265$ $\mathrm{nm}$ and $230 \mathrm{~nm}$. The resulting spectra were shown in the fig: 2
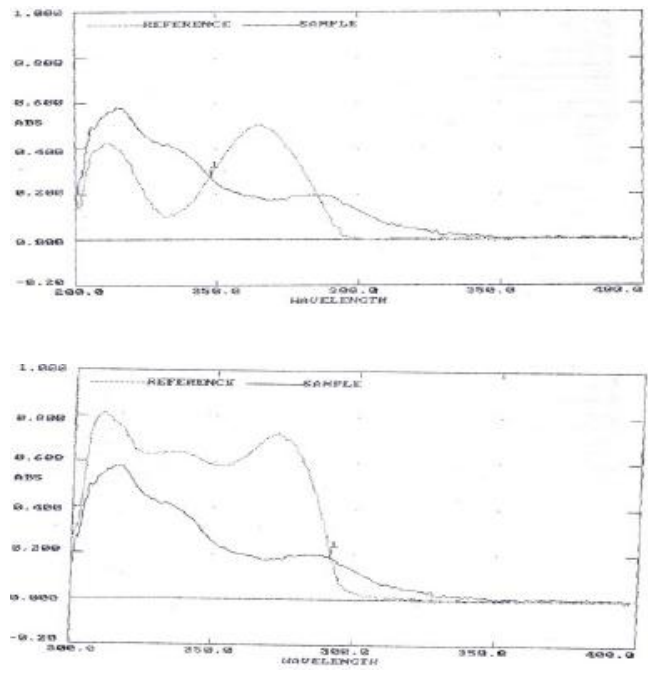

Fig: 2 Overlay UV spectrum of of Lamivudine, zidovudine and nevirapine drugs

\section{Procedure}

A solvent system of Ammonium acetate buffer $\mathrm{pH} 5.5, \mathrm{ACN}$ and $\mathrm{MeOH}$ in the Ratio of $50: 30: 20 \% \mathrm{v} / \mathrm{v}$ was found to be the most suitable mobile phase for ideal separation of Lamivudine, zidovudine, and nevirapine drugs. The mobile phase was pumped through the column at a flow rate of $1.2 \mathrm{ml} / \mathrm{min}$. The column was at an ambient temperature and equilibrated with mobile phase for 30 minutes prior to the injection of solutions. $20 \mu \mathrm{l}$ of five repeat injections of both standard and sample solutions were injected into the chromatographic system and the areas of Lamivudine, zidovudine and nevirapine peak were measured. The detection of drugs was monitored at $260 \mathrm{~nm}$. The runtime was set at $8 \mathrm{~min}$. Under these optimized chromatographic conditions, the retention time for the Lamivudine was $2.457 \mathrm{~min}$, zidovudine was $3.327 \mathrm{~min}$ and nevirapine was $4.813 \mathrm{~min}$, respectively. The typical chromatogram of all three drugs showing the separation of drugs is given in Figures 3and 4. From the peaks of drugs, the \% assay was calculated using the following formula.

$\%$ Assay $=$ ATAS $\times$ WSDS $\times$ DTWT $\times$ P100 $\times$ Avg

WtLC $\times 100$

\section{Method validation}

The validation of analytical method verifies that the characteristics of the method if they satisfy the requirements of the method. The developed method was validated according 
to ICH guidelines for specificity, linearity, accuracy, and precision, LOD,LOQ and robustness.

\section{RESULTS AND SCUSSION}

\section{Method optimization}

Different mobile phases were experienced to develop a liquid chromatographic method for the assay of Lamivudine, zidovudine, and nevirapine.The HPLC method was optimized through the evaluation of several solvent mixtures. Mobile phase of Ammonium acetate buffer $\mathrm{pH}$ 5.5, $\mathrm{ACN}$ and $\mathrm{MeOH}$ in the Ratio of $50: 30: 20 \% \mathrm{v} / \mathrm{v}$ on Inertsil, ODsC18 $4.6 \mathrm{x}$ $150 \mathrm{~mm}, 3.5 \mathrm{~mm}$, column resulted in sharp, well-defined peaks with good resolution and low retention times were about 2.457 min for Lamivudine, 3.326 min zidovudine and $4.810 \mathrm{~min}$ for nevirapine at the flow rate of $1.2 \mathrm{ml} / \mathrm{min}$. The $\%$ assay of Lamivudine, Zidovudine, and Nevirapine present in the tablet dosage form was found to be $98.59 \%, 98.69 \%$, and $100.27 \%$ respectively. Results are shown in table 1

Table: 1 Assay Results of Lamivudine, Zidovudine and Nevirapine

\begin{tabular}{|c|c|c|c|}
\hline \multicolumn{5}{|c|}{ Standard Area } \\
\hline $\begin{array}{c}\text { Injection } \\
\text { No }\end{array}$ & Lamivudine & Zidovudine & Nevirapine \\
\hline 1 & 1529.340 & 3107.866 & 2016.568 \\
\hline 2 & 1529.798 & 3117.090 & 2004.559 \\
\hline 3 & 1516.743 & 3100.112 & 1991.608 \\
\hline 4 & 1526.475 & 3118.032 & 2005.731 \\
\hline 5 & 1524.718 & 3119.845 & 2012.314 \\
\hline Average & 1525.415 & 3112.589 & 2006.156 \\
\hline \multicolumn{4}{|c|}{ Sample area } \\
\hline 1 & 1528.533 & 3119.690 & 2008.710 \\
\hline 2 & 1522.402 & 3104.454 & 2082.342 \\
\hline 3 & 1516.743 & 3100.112 & 2091.608 \\
\hline 4 & 1526.475 & 3118.032 & 2005.731 \\
\hline 5 & 1524.718 & 3119.845 & 2012.314 \\
\hline $\begin{array}{c}\text { Average } \\
\text { Tablet } \\
\text { average } \\
\text { weight }\end{array}$ & $\mathbf{1 5 2 3 . 7 7 4}$ & 3112.427 & 2040.141 \\
\hline Standard & $\mathbf{5 0 . 3} \mathrm{mg}$ & $100 \mathrm{mg}$ & $\mathbf{6 6 . 6} \mathrm{mg}$ \\
\hline
\end{tabular}

\begin{tabular}{|c|c|c|c|}
\hline weight & & & \\
\hline $\begin{array}{c}\text { Sample } \\
\text { weight }\end{array}$ & $250.1 \mathrm{mg}$ & $250.1 \mathrm{mg}$ & $250.1 \mathrm{mg}$ \\
\hline $\begin{array}{c}\text { Label } \\
\text { amount }\end{array}$ & $150 \mathrm{mg}$ & $\mathbf{3 0 0} \mathrm{mg}$ & $200 \mathrm{mg}$ \\
\hline Std.purity & 98.7 & 98.7 & 98.7 \\
\hline Cal.: & $147.89 \mathrm{mg}$ & $\mathbf{2 9 6 . 0 8} \mathbf{~ m g}$ & $\mathbf{2 0 0 . 5 4} \mathbf{~ m g}$ \\
\hline \%Assay & $\mathbf{9 8 . 5 9 \%}$ & $\mathbf{9 8 . 6 9 \%}$ & $\mathbf{1 0 0 . 2 7 \%}$ \\
\hline
\end{tabular}

Study of retention time

A standard dilution of pure drugs having $50 \mu \mathrm{g} / \mathrm{ml}$ of lamivudine, $100 \mu \mathrm{g} / \mathrm{ml}$ of zidovudine and $66.6 \mu \mathrm{g} / \mathrm{ml}$ of nevirapine were prepared in a diluent and loaded injection port of instrument fitted with a $20 \mu 1$ fixed loop. The solution was injected and chromatogram was recorded. The retention time of Lamivudine was $2.457 \mathrm{~min}$, zidovudine was $3.327 \mathrm{~min}$ and nevirapine was $4.813 \mathrm{~min}$. The respective chromatograms of drugs are shown in figures 3 and 4.

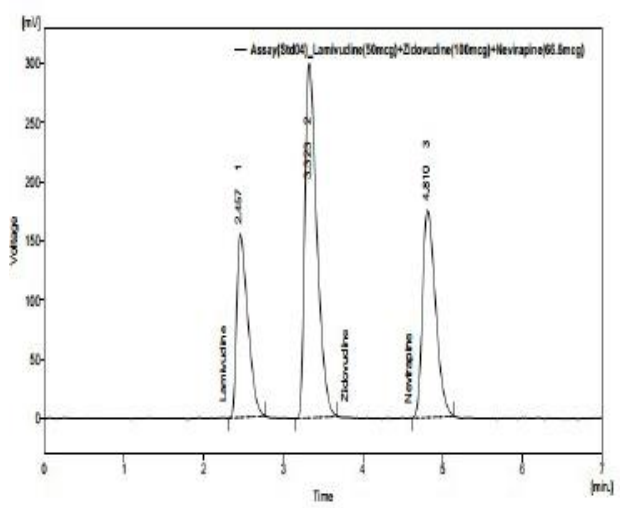

Fig. 3: Typical chromatogram of Lamivudine, zidovudine and nevirapine from standard solution

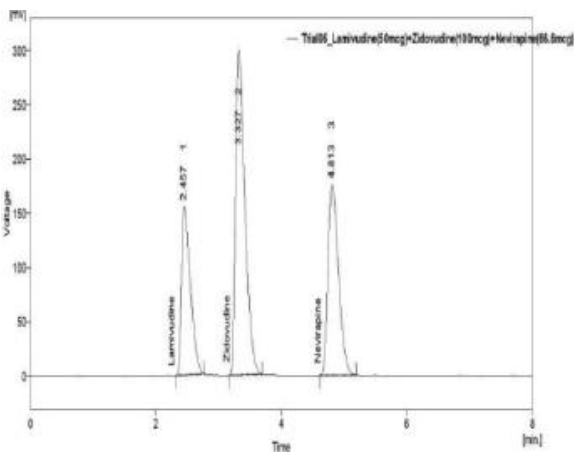

Fig. 4: Typical chromatogram of Lamivudine, zidovudine and nevirapine from sample solution Method validation 


\section{System suitability}

After equilibration of the column with mobile phase, five replicates injections of a $20 \mu \mathrm{l}$ standard solution was injected. The System suitability of the method was evaluated using parameters from the recorded chromatograms by complete separation of lamivudine, zidovudine and nevirapine peaks from standard solution and $\% \mathrm{RSD}$ of replicating injections was less than $1 \%$. The system suitability results are publicized in Table 2.

\begin{tabular}{|c|c|c|c|c|c|c|}
\hline $\begin{array}{l}\text { Name } \\
\text { of the } \\
\text { peak }\end{array}$ & $\begin{array}{l}\text { Rt } \\
\text { min }\end{array}$ & $\begin{array}{l}\text { Peak } \\
\text { Area }\end{array}$ & $\begin{array}{l}\text { Taili } \\
\text { ng }\end{array}$ & $\begin{array}{l}\text { Plate } \\
\text { coun } \\
t \\
\end{array}$ & $\begin{array}{l}\text { Re } \\
\text { Solu } \\
\text { tion } \\
\end{array}$ & $\begin{array}{l}\% \\
\text { RSD }\end{array}$ \\
\hline LMV & 2.46 & 1524.71 & 1.68 & 3166 & - & 0.75 \\
\hline ZDV & 3.32 & 3119.84 & 1.56 & 2297 & 3.154 & 0.56 \\
\hline NVR & 4.81 & 2012.31 & 1.51 & 3967 & 5.058 & 0.38 \\
\hline
\end{tabular}

\section{Specificity}

The specificity of the process was evaluated by injecting blank, sample, and standard preparations into the chromatographic system and chromatograms were compared. It was observed that there was no interference due to excipients from tablet dosage form and also from solvent at retention time of analyte peaks and further more showed good resolution.

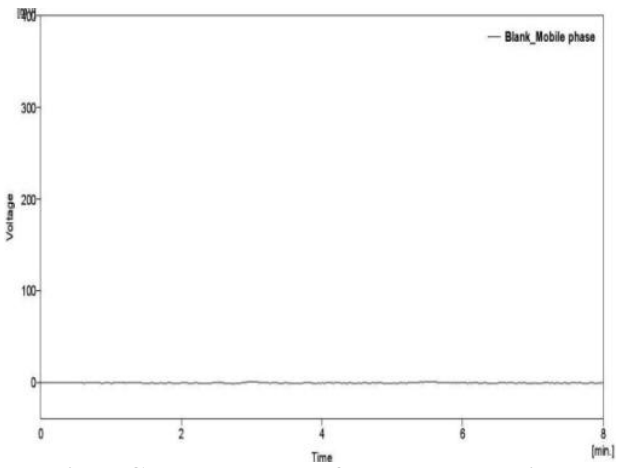

Linearity
The linearity of response (peak area) for Lamivudine, Zidovudine, and Nevirapine in relation to concentration was determined in a concentration ranging from $30-70 \mu \mathrm{g} / \mathrm{ml}$ for Lamivudine, $60-140 \mu \mathrm{g} / \mathrm{ml}$ for Zidovudine and $39.9-93.2 \mu \mathrm{g} / \mathrm{ml}$ for Nevirapine. Each concentration level was injected in replicate in to the HPLC system. The linearity was evaluated by the value of the correlation coefficient. These values for Lamivudine, Zidovudine, and Nevirapine were $0.9997,0.9998$ and 0.9985 and good correlation was obtained between the peak areas and concentrations as shown in figures 6,7 and 8 and the results are shown in Table 3, 4 and 5

Table 3: Linearity results for Lamivudine

\begin{tabular}{|c|c|}
\hline Lamivudine $(\mu \mathrm{g} / \mathrm{ml})$ & Peak area \\
\hline 30 & 1052.087 \\
\hline 40 & 1330.588 \\
\hline 50 & 1508.091 \\
\hline 60 & 1986.835 \\
\hline 70 & 2107.992 \\
\hline Slope & 40.05 \\
\hline Y-intercept & 243 \\
\hline Correlation coefficient (R2) & 0.9997 \\
\hline
\end{tabular}

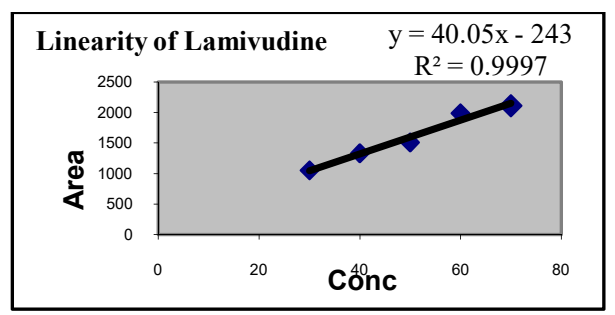

Fig: 6 calibration curve of Lamivudine

Table 4: Linearity results for Zidovudine

\begin{tabular}{|c|c|}
\hline Zidovudine $(\mu \mathrm{g} / \mathrm{ml})$ & Peak area \\
\hline 60 & 2147.573 \\
\hline 80 & 2713.131 \\
\hline 100 & 3084.988 \\
\hline 120 & 3805.769 \\
\hline 140 & 4230.274 \\
\hline Slope & 50.45 \\
\hline Y-intercept & 50.72 \\
\hline Correlation coefficient (R2) & 0.9998 \\
\hline
\end{tabular}




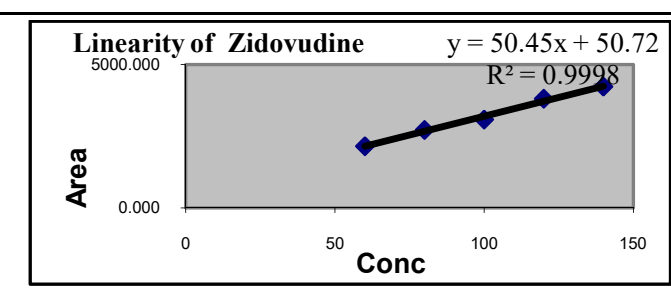

Fig: 7 calibration curve of Zidovudine

Table 5: Linearity results for Nevirapine

\begin{tabular}{|c|c|}
\hline Nevirapine $(\mu \mathrm{g} / \mathrm{ml})$ & Peak area \\
\hline 39.9 & 1363.369 \\
\hline 53.2 & 1759.538 \\
\hline 66.6 & 2092.019 \\
\hline 79.9 & 2486.364 \\
\hline 93.2 & 2742.958 \\
\hline Slope & 26.87 \\
\hline Y-intercept & 175.2 \\
\hline Correlation coefficient (R2) & 0.9985 \\
\hline
\end{tabular}

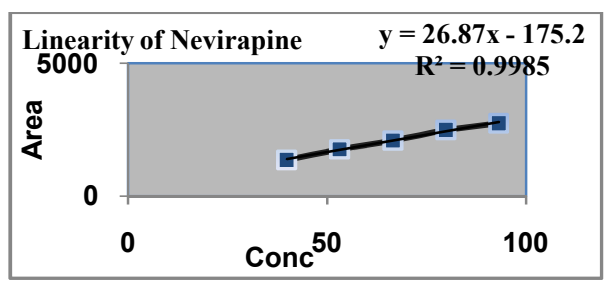

Fig: 8 calibration curve of Nevirapine

\section{Accuracy}

The accuracy of the method was determined by recovery experiments and was performed by the standard addition method at three concentration levels of $80 \%, 100 \%$ and $120 \%$. Each level was injected thrice into the chromatographic system and the percentage and mean $\%$ recoveries for all three drugs were calculated and the results are given away in Table 6, 7 and 8.

Table 6: Recovery results of Lamivudine

\begin{tabular}{|c|c|c|c|c|}
\hline $\begin{array}{l}\text { Accu } \\
\text { racy } \\
\text { level } \\
(\%)\end{array}$ & $\begin{array}{l}\text { Amount } \\
\text { added } \\
\text { (in } \mu g \text { ) }\end{array}$ & $\begin{array}{l}\text { Amount } \\
\text { recovered } \\
\text { (in } \mu \mathrm{g})\end{array}$ & $\begin{array}{l}\text { \%o } \\
\text { Recove } \\
\text { ry }\end{array}$ & $\begin{array}{l}\text { Mean } \\
\% \\
\text { recovery }\end{array}$ \\
\hline 80 & $40+10$ & 49.82 & 99.64 & \multirow{3}{*}{99.60} \\
\hline 80 & $40+10$ & 49.80 & 99.60 & \\
\hline 80 & $40+10$ & 49.78 & 99.56 & \\
\hline 100 & $50+10$ & 59.46 & 99.10 & \multirow{3}{*}{99.15} \\
\hline 100 & $50+10$ & 59.52 & 99.20 & \\
\hline 100 & $50+10$ & 59.50 & 99.16 & \\
\hline 120 & $60+10$ & 69.78 & 99.68 & \multirow{3}{*}{99.72} \\
\hline 120 & $60+10$ & 69.81 & 99.72 & \\
\hline 120 & $60+10$ & 69.85 & 99.78 & \\
\hline
\end{tabular}

Table 7: Recovery results of Zidovudine

\begin{tabular}{|c|c|c|c|c|}
\hline $\begin{array}{l}\text { Accu } \\
\text { racy } \\
\text { level } \\
(\%)\end{array}$ & $\begin{array}{l}\text { Amount } \\
\text { added } \\
\text { (in } \mu g \text { ) }\end{array}$ & $\begin{array}{l}\text { Amount } \\
\text { recovered } \\
(\text { in } \mu \mathrm{g})\end{array}$ & $\begin{array}{c}\% \\
\text { Recove } \\
\text { ry }\end{array}$ & $\begin{array}{c}\text { Mean } \\
\% \\
\text { recovery }\end{array}$ \\
\hline 80 & $80+20$ & 98.34 & 98.34 & \multirow{3}{*}{98.54} \\
\hline 80 & $80+20$ & 98.55 & 98.55 & \\
\hline 80 & $80+20$ & 98.75 & 98.75 & \\
\hline 100 & $100+20$ & 120.05 & 100.04 & \multirow{3}{*}{100.03} \\
\hline 100 & $100+20$ & 120.01 & 100.00 & \\
\hline 100 & $100+20$ & 120.04 & 100.05 & \\
\hline 120 & $120+20$ & 137.55 & 98.25 & \multirow{3}{*}{98.58} \\
\hline 120 & $120+20$ & 138.01 & 98.57 & \\
\hline 120 & $120+20$ & 138.50 & 98.92 & \\
\hline
\end{tabular}

\begin{tabular}{|c|c|c|c|c|}
\hline $\begin{array}{c}\text { Accu } \\
\text { racy } \\
\text { Level } \\
(\%)\end{array}$ & $\begin{array}{c}\text { Amount } \\
\text { added } \\
\text { (in } \mu \text { g) }\end{array}$ & $\begin{array}{l}\text { Amount } \\
\text { recovered } \\
\text { (in } \mu \mathrm{g})\end{array}$ & $\begin{array}{c}\% \% \\
\text { Recove } \\
\text { ry }\end{array}$ & $\begin{array}{c}\text { Mean } \\
\% \\
\text { recov } \\
\text { ery }\end{array}$ \\
\hline 80 & $53.2+13.34$ & 66.52 & 99.96 & \multirow{3}{*}{99.91} \\
\hline 80 & $53.2+13.34$ & 66.49 & 99.92 & \\
\hline 80 & $53.2+13.34$ & 66.45 & 99.86 & \\
\hline 100 & $66.6+13.34$ & 79.90 & 99.94 & \multirow{3}{*}{99.89} \\
\hline 100 & $66.6+13.34$ & 79.86 & 99.89 & \\
\hline 100 & $66.6+13.34$ & 79.82 & 99.84 & \\
\hline 120 & $79.9+13.34$ & 99.92 & 99.65 & \multirow{3}{*}{99.60} \\
\hline 120 & $79.9+13.34$ & 99.88 & 99.61 & \\
\hline 120 & $79.9+13.34$ & 92.82 & 99.54 & \\
\hline
\end{tabular}

\section{Precision}

The precision of the method was demonstrated by repeatability and intermediate precision studies. Intermediate precision (inter-day precision) was evaluated by assaying six injections of sample solution according to the description of the analytical method by different analysts on different days using different HPLC and columns of the same make but different lot number. The \% RSD for response factor of all three drugs was found to be less than $2 \%$ and results are revealed in tables 9,10 and 11 .

Table: 9 Repeatability Results for Lamivudine

\begin{tabular}{|l|l|l|l|l|l|}
\hline S.No & $\begin{array}{l}\text { Peak } \\
\text { name }\end{array}$ & $\begin{array}{l}\text { Rt } \\
\text { (min) }\end{array}$ & $\begin{array}{l}\text { Peak } \\
\text { Area }\end{array}$ & $\begin{array}{l}\text { Plate } \\
\text { count }\end{array}$ & $\begin{array}{l}\text { Asym } \\
\text { metry }\end{array}$ \\
\hline 1 & LMV & 2.463 & 1532.16 & 4370 & 1.346 \\
\hline 2 & LMV & $\mathbf{2 . 4 5 7}$ & 1533.75 & 4362 & 1.346 \\
\hline 3 & LMV & 2.457 & 1533.46 & 4362 & 1.480 \\
\hline 4 & LMV & $\mathbf{2 . 4 6 0}$ & 1527.64 & 4366 & 1.440 \\
\hline 5 & LMV & $\mathbf{2 . 4 6 3}$ & $\mathbf{1 5 3 3 . 0 1}$ & $\mathbf{4 3 7 0}$ & $\mathbf{1 . 3 4 6}$ \\
\hline 6 & LMV & $\mathbf{2 . 4 5 7}$ & $\mathbf{1 5 2 8 . 5 2}$ & $\mathbf{4 3 6 2}$ & $\mathbf{1 . 3 4 6}$ \\
\hline & Mean & $\mathbf{2 . 4 5 9 5}$ & $\mathbf{1 5 3 1 . 4 2}$ & & \\
\hline & SD & $\mathbf{0 . 0 0 3}$ & $\mathbf{2 . 3 3 8}$ & & \\
\hline & \%RSD & $\mathbf{0 . 1 3}$ & $\mathbf{0 . 1 5}$ & & \\
\hline
\end{tabular}

Table: 10 Repeatability Results for Zidovudine 


\begin{tabular}{|c|c|c|c|c|c|}
\hline S.No. & $\begin{array}{c}\text { Peak } \\
\text { name }\end{array}$ & $\begin{array}{c}\text { Rt } \\
\text { (min) }\end{array}$ & $\begin{array}{c}\text { Peak } \\
\text { Area }\end{array}$ & $\begin{array}{c}\text { Plate } \\
\text { count }\end{array}$ & $\begin{array}{c}\text { Asym } \\
\text { metry }\end{array}$ \\
\hline 1 & ZDV & $\mathbf{3 . 3 3 0}$ & $\mathbf{3 1 1 4 . 8 4}$ & $\mathbf{3 3 0 3}$ & $\mathbf{1 . 1 7 2}$ \\
\hline 2 & ZDV & $\mathbf{3 . 3 2 3}$ & $\mathbf{3 1 2 5 . 2 9}$ & $\mathbf{3 2 9 4}$ & $\mathbf{1 . 1 0 0}$ \\
\hline 3 & ZDV & $\mathbf{3 . 3 2 3}$ & $\mathbf{3 1 1 7 . 2 7}$ & $\mathbf{3 2 9 4}$ & $\mathbf{1 . 0 6 7}$ \\
\hline 4 & ZDV & $\mathbf{3 . 3 2 7}$ & $\mathbf{3 1 1 8 . 7 7}$ & $\mathbf{3 2 9 8}$ & $\mathbf{1 . 1 7 2}$ \\
\hline 5 & ZDV & $\mathbf{3 . 3 3 0}$ & $\mathbf{3 1 1 9 . 6 7}$ & $\mathbf{1 . 3 4 6}$ & $\mathbf{1 . 1 0 0}$ \\
\hline $\mathbf{6}$ & ZDV & $\mathbf{3 . 3 2 3}$ & $\mathbf{3 1 1 2 . 3 3}$ & $\mathbf{3 2 0 3}$ & $\mathbf{1 . 1 0 0}$ \\
\hline & Mean & $\mathbf{3 . 3 2 6}$ & $\mathbf{3 1 1 8 . 0 3}$ & & \\
\hline & SD & $\mathbf{0 . 0 0 3}$ & $\mathbf{4 . 4 5 1}$ & & \\
\hline & \%RSD & $\mathbf{0 . 1 0}$ & $\mathbf{0 . 1 4}$ & & \\
\hline
\end{tabular}

Table: 11 Repeatability Results for Nevirapine

\begin{tabular}{|c|c|c|c|c|c|}
\hline S.N & $\begin{array}{c}\text { Peak } \\
\text { name }\end{array}$ & $\begin{array}{c}\text { Rt } \\
\text { (min) }\end{array}$ & $\begin{array}{c}\text { Peak } \\
\text { Area }\end{array}$ & $\begin{array}{c}\text { Plate } \\
\text { count }\end{array}$ & $\begin{array}{c}\text { Asym } \\
\text { metry }\end{array}$ \\
\hline 1 & NVR & 4.817 & 2016.05 & 3967 & $\mathbf{1 . 7 5 7}$ \\
\hline 2 & NVR & 4.810 & 1998.32 & 3813 & $\mathbf{1 . 7 0 7}$ \\
\hline 3 & NVR & 4.807 & 2013.29 & 3951 & 1.730 \\
\hline 4 & NVR & 4.813 & 2008.86 & 3961 & 1.730 \\
\hline 5 & NVR & 4.817 & 2014.13 & 3967 & 1.180 \\
\hline 6 & NVR & 4.807 & 2009.16 & 3951 & 1.730 \\
\hline & Mean & $\mathbf{4 . 8 1 2}$ & $\mathbf{2 0 0 9 . 9 7}$ & & \\
\hline & SD & $\mathbf{0 . 0 0 5}$ & $\mathbf{6 . 3 6 8}$ & & \\
\hline \multicolumn{7}{|c|}{ \%RSD } & $\mathbf{0 . 1 0}$ & $\mathbf{0 . 3 2}$ & & \\
\hline
\end{tabular}

Limit of detection (LOD) and limit of quantification (LOQ)

The limit of detection and quantification were assessed based on the signal to noise ratio. This ratio for LOD is $3: 1$ and LOQ is 10:1.The limit of detection and quantification were evaluated from the calibration curves by applying statistical calculations and results are shown in table 12.

The limit of detection and the limit of quantification were expressed as :

\section{LOD $=3.3 \sigma / \mathrm{S}$ \\ $L O Q=10.0 \sigma / S$ \\ Where;}

$\sigma=$ Standard deviation of the response

$S=$ Slope of the regression line

Table:12 LOD and LOQ results for Lamivudine, Zidovudine and Nevirapine

\begin{tabular}{|c|c|c|}
\hline Name of the analyte & LOD $\mu \mathrm{g} / \mathrm{ml}$ & $\mathrm{LOQ} \mu \mathrm{g} / \mathrm{ml}$ \\
\hline Lamivudine & 1.30 & 3.95 \\
\hline Zidovudine & 3.97 & 12.03 \\
\hline Nevirapine & 2.66 & 8.06 \\
\hline
\end{tabular}

\section{Robustness}

Robustness of the method were demonstrated by analyzing the system suitability parameters under deliberately modified chromatographic conditions such as flow rate, and wavelength on lower and higher side of the original values. There was no significant change in the retention time between the original method and changes made to the method. The results are illustrated in Table 13,14 and 15

Table: 13 system suitability results for robustness study of

\begin{tabular}{|c|c|c|c|c|c|}
\hline $\begin{array}{c}\text { Robust } \\
\text { condition }\end{array}$ & $\begin{array}{c}\text { Rt } \\
(\mathrm{min})\end{array}$ & $\begin{array}{c}\text { Peak } \\
\text { Area }\end{array}$ & $\begin{array}{c}\text { Taili } \\
\text { ng }\end{array}$ & $\begin{array}{c}\text { Plate } \\
\text { count }\end{array}$ & $\begin{array}{c}\% \\
\text { RSD }\end{array}$ \\
\hline Normal & 2.460 & 1524.71 & 1.68 & 3166 & 0.75 \\
\hline $\begin{array}{c}\text { FR } \\
1.0 \mathrm{ml}\end{array}$ & 2.937 & 1839.01 & 1.50 & 4323 & 0.79 \\
\hline $\begin{array}{c}\text { FR } \\
1.4 \mathrm{ml}\end{array}$ & 2.140 & 1313.54 & 1.12 & 4427 & 0.82 \\
\hline $\begin{array}{c}\text { WL } \\
258 \mathrm{~nm}\end{array}$ & 2.457 & 1505.60 & 1.34 & 4362 & 0.86 \\
\hline $\begin{array}{c}\text { WL } \\
262 \mathrm{~nm}\end{array}$ & 2.460 & 1611.07 & 1.34 & 3198 & 0.73 \\
\hline \multicolumn{2}{|c|}{} & & & & \\
\hline
\end{tabular}

Table: 14 system suitability results for robustness study of

\begin{tabular}{|c|c|c|c|c|c|c|}
\hline $\begin{array}{c}\text { Robust } \\
\text { conditi } \\
\text { on }\end{array}$ & $\begin{array}{c}\text { Rt } \\
(\mathrm{min})\end{array}$ & $\begin{array}{l}\text { Peak } \\
\text { Area }\end{array}$ & $\begin{array}{c}\text { Taili } \\
\text { ng }\end{array}$ & $\begin{array}{c}\text { Plate } \\
\text { coun } \\
t \\
\end{array}$ & $\begin{array}{c}\operatorname{Re} \\
\text { solut } \\
\text { ion }\end{array}$ & $\begin{array}{c}\% \\
\text { RSD }\end{array}$ \\
\hline Normal & 3.327 & $\begin{array}{c}3119 \\
.84\end{array}$ & 1.56 & 2297 & 3.15 & 0.56 \\
\hline $\begin{array}{l}\text { FR } \\
1.0 \\
\text { ml } \\
\end{array}$ & 3.967 & $\begin{array}{c}3764 \\
.63\end{array}$ & 1.29 & 3254 & 3.13 & 0.65 \\
\hline $\begin{array}{l}\text { FR } \\
1.4 \\
\text { ml }\end{array}$ & 2.890 & $\begin{array}{c}2648 \\
.87\end{array}$ & 1.96 & 3365 & 3.22 & 0.76 \\
\hline $\begin{array}{l}\text { WL } \\
258 \\
n m\end{array}$ & 3.320 & $\begin{array}{c}3004 \\
.85\end{array}$ & 1.06 & 4366 & 3.14 & 0.72 \\
\hline $\begin{array}{c}\text { WL } \\
262 \mathrm{~nm}\end{array}$ & 3.327 & $\begin{array}{c}3312 \\
.39 \\
\end{array}$ & 1.06 & 3207 & 3.15 & 0.58 \\
\hline
\end{tabular}

Table: 15 system suitability results for robustness study of

\begin{tabular}{|c|c|c|c|c|c|c|}
\hline \multicolumn{7}{|c|}{ Nevirapine } \\
\hline $\begin{array}{c}\text { Rob } \\
\text { ust } \\
\text { con } \\
\text { dition }\end{array}$ & $\underset{(\mathbf{m i n})}{\mathbf{R t}}$ & $\begin{array}{l}\text { Peak } \\
\text { Area }\end{array}$ & $\begin{array}{l}\text { Ta } \\
\text { ili } \\
\text { ng }\end{array}$ & $\begin{array}{l}\text { Plate } \\
\text { count }\end{array}$ & $\begin{array}{c}\text { Re } \\
\text { solut } \\
\text { ion }\end{array}$ & $\begin{array}{c}\% \\
\text { RSD }\end{array}$ \\
\hline $\begin{array}{l}\text { Nor } \\
\text { mal }\end{array}$ & 4.817 & $\begin{array}{c}2012 . \\
31\end{array}$ & $\begin{array}{c}1.5 \\
1\end{array}$ & 3967 & 5.05 & 0.38 \\
\hline $\begin{array}{l}\text { FR } \\
1.0 \\
\text { ml }\end{array}$ & 5.743 & $\begin{array}{c}2435 \\
68\end{array}$ & $\begin{array}{c}1.8 \\
6\end{array}$ & 3893 & 5.05 & 0.45 \\
\hline $\begin{array}{l}\text { FR } \\
1.4 \\
\text { ml }\end{array}$ & 4.180 & $\begin{array}{c}1714 . \\
57\end{array}$ & $\begin{array}{c}0.1 \\
5\end{array}$ & 3944 & 5.11 & 0.62 \\
\hline $\begin{array}{l}\mathrm{WL} \\
258 \\
\mathrm{~nm}\end{array}$ & 4.807 & $\begin{array}{c}2084 . \\
01\end{array}$ & $\begin{array}{c}1.7 \\
3\end{array}$ & 3951 & 5.04 & 0.52 \\
\hline $\begin{array}{l}\text { WL } \\
262 \\
\mathrm{~nm}\end{array}$ & 4.817 & $\begin{array}{c}2022 . \\
59\end{array}$ & $\begin{array}{c}1.6 \\
8\end{array}$ & 3824 & 5.01 & 0.36 \\
\hline
\end{tabular}

\section{CONCLUSION}


From the above experimental results, the projected method for the simultaneous estimation of Lamivudine, Zidovudine and Nevirapine in their combined dosage form was found to be simple, precise, accurate and high resolution. Also, the lower solvent consumption and shorter retention time lead to more acceptable, cost effective and Eco friendly chromatographic procedure. Hence it can be conveniently adopted for routine analysis in quality control department

\section{ACKNOWLEDGEMENTS}

This work was supported by St. Mary`s college of pharmacy and Salycilates and chemicals Pvt.Ltd.The authors would like to thank for providing research facilities.

\section{REFERENCES}

[1] 2009. Guidelines for the use of Antiretroviral agents in Pediatric HIV infection, developed by working group on antiretroviral therapy and medical management of HIV infected children convened by the National resource center at the Francois Xavier bagnoud center, UMDJ, the health resources and services administration (HSRA) and the National Institutes of health (NIH).

[2] WHO. 2006. World Health Organization. Pediatric guideline on Antiretroviral theray of HIV infection in infants and children in resource limited settings: towards universal access.

[3] WHO. 2009. Towards universal access: scaling up priority HIV/AIDS interventions in the health sector: progress report

[4] Brunton LL, Chabner BA, Knollmann BC, eds. 2011. Goodman \& Gilman's The Pharmacological Basis of Therapeutics

[5] Katlama C, Ingrand D, Loveday C, Clumeck N, Mallolas J, Staszewski S, et al.: Safety and efficacy of lamivudine-zidovudine combination therapy in antiretroviral-naive patients. A randomized controlled comparison with zidovudine monotherapy Lamivudine European HIV Working Group. JAMA; 276; (2) 1996; 118-25.

[6] Palella FJ, Jr., Delaney KM, Moorman AC, Loveless MO, Fuhrer J, Satten GA, et al.: Declining morbidity and mortality among patients with advanced human immunodeficiency virus infection. HIV Outpatient Study Investigators. N Engl J Med 338;(13); 1998; 853-60.

[7] Vaishali P. Nagulwar and Dr. Kishor P. Bhusari A validated UV spectrophotometric method for the simultaneous estimation of Lamivudine, Nevirapine and zidovudine in combined tablet dosage form Journal of Pharmacy Research 2(4), 2009, 666-669.

[8] *Ramesh Jayaprakash, Senthil Kumar Natesan, Vijay Amirtharaj Ramasamy, Rajasekhar Kommi, Kiran Gandhi R. Simultaneous equation method for the estimation of Lamivudine, Nevirapine and Zidovudine in Bulk and tablet 
dosage forms Journal of

Pharmaceutical Chemistry, 1 (3), 2014, 55-58.

[9] Anantha Kumar1 D., Naveen Babu1 M.V. , Seshagiri Rao J.V.L.N. and Jayathirtha Rao .V., Simultaneous determination of lamivudine, zidovudine and nevirapine in tablet dosage forms by RP-hplc method Rasayan Jr of chemistry Vol.3, (No.1), 2010, 94-99.

[10] Patel, Vandana B.; Patel, Parag R.; Dasandi, Bhavesh D.; Shivprakash; Patel, Deepa; Bapna, Mayank Simultaneous determination of lamivudine/zidovudine/nevirapine in human plasma using RP-HPLC. Journal of Pharmacy Research; Vol. 3, (Issue 9), Sep2010, p2322.

[11] Vamshi Krishna. P. V., Vinod Kumar. K, Ramalingam. P,. Ramesh. N, C. Harish Kumar Raju. C, Sreeram. B Simultaneous Determination of Lamivudine, Zidovudine and Nevirapine in Tablet Dosage Forms by RP-HPLC Am. J. PharmTech Res. 2(4); 2012.

[12] Anjali Joshi and Moji Christianah Adeyeye Reversed Phase LC-UV Method Development and Validation for Simultaneous determination of three antiretrovirals: Lamivudine, Zidovudine, Nevirapine and Possible Degradants in a Fixed Dose Pharmaceutical Product. Journal of Pharmaceutical Technology \& Drug Research Vol.1; 2012; 1-8
[13] Sindhura D, Nanda Kishore Agarwal. Analytical method development and validation for the simultaneous estimation of lamivudine, zidovudine and efavirenz by RP-hplc in bulk and pharmaceutical dosage forms Indian Journal of Research in Pharmacy and Biotechnology 1,(5) ,2013, 583-588

[14] Dharmaraj Santhosam. S, Adiyaman. E. and Senthilkumar. M. Development and. Validation of RPHPLC Method for the Simultaneous Estimation of Lamivudine, Zidovudine and Nevirapine from Bulk and Tablet Dosage Form. International Journal of. Pharmaceutical and Chemical Sciences. 2(4): 2013

[15] Sunitha. T T. Sindhuri. P 3, and C. Palavan. C A New RP-HPLC Method for the Simultaneous Estimation of Lamivudine, Zidovudine and Nevirapine in Tablet Dosage Forms J. Pharm. Bioanal. Sci., Volume 2, (Issue 1), Jan-Mar 2013, 13-18

[16] Kokkula Sandhya, Nagi Reddy. N, Raja Manohar, Rajashekar. P, RP- HPLC method development and validation for simultaneous estimation of lamivudine, idovudine and nevirapine in tablet dosage form, Indo. American Journal of Pharmaceutical Research, 4 (4), 2014, 2133-2140.

[17] Shinde G.S, Gayke A.U, Bagul.T.P, Aglave .S.B, Rawat.S.S, and N.P.Jain Quantitative Estimation and Validation Of Lamivudine, 
Zidovudine And Nevirapine In

Pharmaceutical Formulation Int. J. Adv. Res. Biol.Sci. 1(9): (2014): 196-203.

[18] Satyanarayana. P, Pavankumar. K.L.N.N.S.V.K, Srinivasa Rao A, G. Subrahmanya Sastry. G. A validated reverse phase hplc method for the simultaneous estimation of lamivudine,stavudine and nevirapine in pharmaceutical dosage forms world journal of pharmacy and pharmaceutical sciences. Volume 4, Issue 09, 1748-1761.

[19] Mohammed Ishaq. $B$, Vanitha Prakash. K, Krishna Mohan. G. Validated RP-HPLC-PDA method for simultaneous determination of Zidovudine, Lamivudine, and Nevirapine in pharmaceutical formulation Drug Development and Therapeutics. Vol. 6 (Issue 1) JanJun 2015.

[20] Murali Krishna Mattaa,Nageswara Rao Pillia,Jaswanth Kumar Inamadugub , Laxminarayana Burugulaa, Seshagiri Rao JVLNc,, Simultaneous quantitation of lamivudine, zidovudine and nevirapine in human plasma by liquid chromatography-tandem mass spectrometry and application to a pharmacokinetic study Acta Pharmaceutica Sinica B 2(5): 2012; 472-480.

[21] Utpal Nandi, Ayan Das, Bikash Roy, Hira Choudhury, Bapi Gorain and Tapan Kumar Pal Development and validation of an HPLC-UV method for simultaneous determination of zidovudine, lamivudine, and nevirapine in human plasma and its application to pharmacokinetic study in human volunteers volume 5, (Issue 6) June 2013 Pages 485-491.

[22] Srinivasa Reddy, Licto Thomas, K. S. Santoshkumar, Nirmala Nayak, Arindam Mukhopadhyay and Saral Thangam A LC-MS/MS method with column coupling technique for simultaneous estimation of lamivudine, zidovudine, and nevirapine in human plasma Journal of Analytical Science and Technology 7:17; (2016).

[23] ICH Topic Q 2 (R1) Validation of Analytical Procedures: Text and Methodology. 